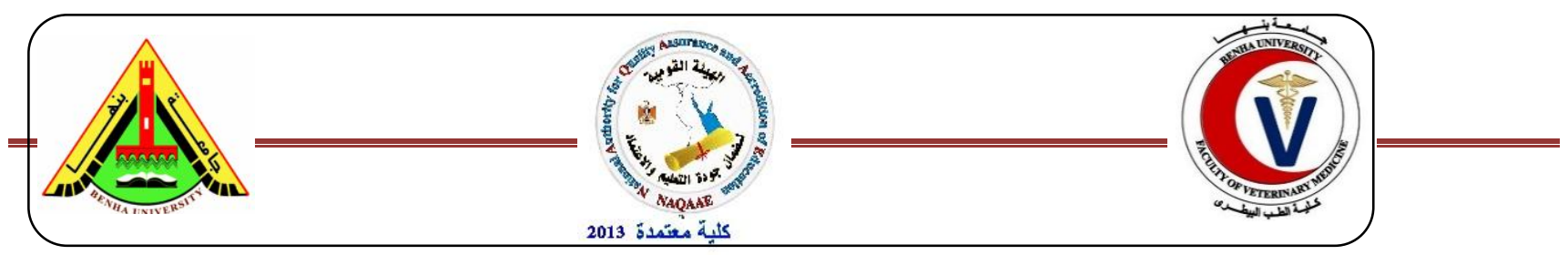

\title{
Immunomodulatory and antiparasitic effects of garlic extract loaded on zinc oxide nanoparticles compared with pure garlic extract on Eimeria stiedae- infected rabbits
}

\author{
Mouchira M. Mohi-Eldin, Mohie A. M. Haridy, Atef Mohammed Hussein Khalil and Karima \\ Abdelnaeim \\ Department of Pathology \& Clinical Pathology, Faculty of Veterinary Medicine, South Valley \\ University, Qena 83523, Egypt \\ Corresponding: Mesho_path@yahoo.com Mouchiapath@vet.svu.edu.eg
}

\begin{abstract}
The study aimed to investigate the immunomodulatory and antiparasitic effects of garlic extract- loaded zinc oxide nanoparticles in comparison to pure garlic extract against rabbit hepatic coccidiosis. Sixty male rabbits were allocated into four groups; Group 1: control, Group 2 (infected group): rabbits were inoculated orally with $2 \times 10^{3}$ sporulated oocyst of E. stiedae, Group 3: rabbits were infected as group 2 and treated with garlic extract $(500 \mathrm{mg} / \mathrm{kg}$ b.w) and Group 4: rabbits infected and treated with garlic extract nanoparticles $(500 \mathrm{mg} / \mathrm{kg} \mathrm{b.w})$. Five rabbits of each group were scarified at $7^{\text {th }}, 14^{\text {th }}$ and $21^{\text {th }}$ day post inoculation (dpi). Biochemical, haematology and antioxidant parameters were evaluated. Fecal samples were collected at $19^{\text {th }}$ day to calculate the number of oocyst. Results revealed: hemoglobin concentration and PCV significantly increased in group 4 when compared to group 2, and platelets count of group 3 significatly increased when compared with group 2. Significant decreases in ALT, AST, Alkaline. phosphatase, bilirubin were detected in groups 3 and 4 compared with group 2, but significant decreases in MDA and SOD in groups $3 \& 4$ compared with group 2. Group 2 had significant increases in ALT, AST, Alkaline phosphatase, bilirubin, MDA and SOD activities when compared with control group. Significant increases in AST and ALP activities were detected in group 4 in comparison with group 3. Group 3 had a significant decrease in SOD when compared with group 4. Group 3 and 4 induced significant reduction in fecal oocyst count compared with group 2. Conclusively, garlic crude extract and garlic nanoparticles had antioxidative and anti-parasitic effect on hepatic coccidiosis of rabbit.
\end{abstract}

Keywords: Garlic nanoparticle, garlic extract, Eimeria stiedae, antioxidant (http://www.bvmj.bu.edu.eg) (bvmj, 35(1): 94-105, SEPT., 2018

\section{INTRODUCTION}

Eimeria stiedae is one of the most pathogenic Eimeria species of domestic rabbits. E. stiedae parasitizes the epithelial cells of the bile duct, causing severe liver damage and great economic losses (Hung et al., 1984).

A nanoparticle (or nanopowder or nanocluster or nanocrystal) is a microscopic 
particle with at least one dimension less than $100 \mathrm{~nm}$ (Leela and Vivekanandan 2008). Nanoparticles (NP), with the advantage of nano-scale particle size facilitates the penetration of NP through the membrane of micro-organisms, could enhance the efficacy of usual anti-parasitic agent (Moghimi et al., 2001; McCarron et al., 2007).

Garlic (Allium sativum) is a medicinal plant that has historically been used for the treatment and prevention of some diseases (Rivlin 2001). Garlic has many pharmacological properties, such as antimicrobial (Goncagul et al., 2010; Ankri et al., 1999), antioxidant (Ramoutar et al., 2010; Sun 2006), and anticancer activity (Antony et al., 2011; Nagini et al., 2008). Garlic and its components have potent anti-parasitic activities against many human and animal parasites (Anthony et al., 2005), such as Leishmania (Wabwoba et al., 2010; GamboaLeon et al., 2007), Schistosoma (Mantawy et al., 2011; Nahed et al., 2009), Trypanosoma, Giardia, Entamoeba (Lun et al., 1994; Ankri et al., 1997) and Plasmodium (Perez et al., 1994; Coppi et al., 2006). Furthermore, garlic has immunostimulatory activities (Tsao et al., 2001; Clement et al., 2010). Also, garlic is able to act as anti-oxidant for inhibiting lipid peroxidation leading to hepatoprotection (Khanum et al., 1998). In addition, there is a widespread belief that garlic prolongs life by lowering blood pressure and cholesterol level and consequently it reduces heart attacks (McMahon et al., 1993; Orekhov et al., 1995; Phelps et al., 1993). Thiosulphinates compounds are responsible for the biological activities of garlic (Amagase, 2001). This experiment is to investigate the anti-parasitic activity of garlic extracts and garlic nanoparticles against E. stiedae- hepatic infection.

\section{MATERIALS AND METHODS}

\subsection{Materials :}

\subsubsection{Experimental animals:}

Sixty male White New Zealand rabbits (4 - 6 weeks old and weighting 300-900 g) were purchased from Local farm in Qeft city, Qena Governorate. All animals were housed in clean cages (two rabbits in each) and given standard diet and clean water ad libitum. Cages were placed in an air-conditioned room $\left(23 \pm 3^{\circ} \mathrm{C}\right)$ with 12:12 hour light: dark cycle. Animals were kept for two weeks before starting of the experiment for acclimatization, during which they subjected for clinical and laboratory examinations to confirm that they were free of E. stiedae- infection. Fecal samples were collected from all rabbits and examined by flotation method using McMaster chamber for counting to prove rabbits free from infection.

\subsubsection{Preparation of the parasite oocysts for experimental infection}

Oocysts of E. stiedae were collected from liver nodules and gall bladder lumen of naturally infected rabbits (from fields). The oocytes were concentrated by conventional floatation method and were allowed to be sporulated in $2.5 \%$ potassium dichromate for 3-5 days and were stored for experimental infection.

\subsubsection{Garlic extracts preparation:}

\subsubsection{Pure garlic extract:}

Dried garlic powder purchased from local market. The powder was mixed with distilled water at concentration of $80 \mathrm{mg} / \mathrm{ml}$ and left overnight incubation (Balasenthil, et al., 1999). Mixed water was centrifuged at 
$3500 \mathrm{rpm}$ for 10 minutes and supernatant was kept in refrigerator at $4^{\circ} \mathrm{C}$ until used.

\subsubsection{Garlic-Zinc oxide nanoparticles:}

Zinc oxide nanoparticles loaded with garlic extract was prepared in Nanotechnology laboratory, Faculty of Science, South Valley University. Sodium hydroxide $(\mathrm{NaOH}) \quad 0.4$ molar was dropped wisely in a 0.1 molar of Zinc oxide. Garlic nano-powder was prepared by ball milling through adding the garlic extract to the aforementioned solution. The mix was stirred for $2 \mathrm{~h}$, and then was dried on hot plate for another $2 \mathrm{~h}$ at $100{ }^{\circ} \mathrm{C}$. The obtained grains (garlic extract nanoparticles) are ready to use in the experimental design. Zinc Oxide nanoparticles (NPs) loaded with garlic extract was prepared by an emulsion polymerization method according to (Luo et al., 2009).

\subsection{Methods}

\subsubsection{Experimental design:}

Sixty male rabbits of 4 - 6 Weeks old randomly divided into four groups $(n=15$ rabbits): Group 1: The rabbits were kept without exposure to either parasitic infection or garlic treatment and used as control group. They orally administrated with $1 \mathrm{ml}$ distilled water for 31 days.

Group 2: The rabbits were given $1 \mathrm{ml}$ of distilled water for 9 days. At the $10^{\text {th }}$ day the animals were inoculated with one dose of $1 \mathrm{ml}$ distilled water containing $\left(2 \times 10^{3}\right.$ sporulated oocysts) of E. stiedae.

Group 3: The rabbits were given $1 \mathrm{ml}$ of distilled water containing $(500 \mathrm{mg} / \mathrm{kg}$ b.wt ) of garlic extract orally for 31 days (along the experiment) and one dose of $1 \mathrm{ml}$ distilled water containing ( $2 \times 10^{3}$ sporulated oocysts) of E. stiedae at the $10^{\text {th }}$ day of the experiment.
Group 4: The rabbits were given $1 \mathrm{ml}$ of distilled water containing zinc oxide nanoparticles loaded on garlic extract (500mg/kg b. w.) orally for 31 days (along the experiment) and one dose of $1 \mathrm{ml}$ distilled water containing $\left(2 \times 10^{3}\right.$ sporulated oocysts) of E. stiedae at the $10^{\text {th }}$ day of the experiment.

Five rabbits of each group were sacrificed at $7^{\text {th }}, 14^{\text {th }}$ and $21^{\text {th }}$ post-infection with E. stiedae. Blood samples were collected by heart puncture before scarified for biochemical and hematological examinations.

\subsubsection{Hematological Analyses:}

Blood samples were collected from all animals using an anticoagulant (EDTA) for hematological examinations that included red and white blood cell (RBC \& WBCs) counts, hemoglobin concentration $(\mathrm{Hb})$, packed cell volume (PCV \%), mean corpuscular volume (MCV), mean corpuscular hemoglobin $(\mathrm{MCH})$ and mean corpuscular hemoglobin concentration (MCHC). Blood films were prepared and stained by Giemsa stain for differential leucocytic counts.

\subsubsection{Biochemical examination:}

Clear serum samples were obtained by centrifugation at 3,000 rpm for $15 \mathrm{~min}$. Serum was kept in the refrigerator at $-40{ }^{\circ} \mathrm{C}$ until used for biochemical analysis, which included liver functions (Aspartate aminotransferase (AST), Alanine aminotransferase (ALT), alkaline Phosphatase (ALP), (Biodiagnostics, Egypt). Total bilirubin, total protein and albumin (Spectrum - diagnostic kits). Antioxidant activities were evaluated for Malondialdehyde (MDA) and Superoxide Dismutase (SOD) using Biodiagnostic kits.

\subsubsection{Fecal oocyst count:}


Single individual fecal specimens were collected from each group for parasitological examination at day 19 PC. One gm of feces from each sample was taken and the number of oocysts per gram of fecal matter was counted using the McMaster method (long and Joyner, 1976).

\subsubsection{Statistical analysis}

Statistical analysis was performed with the statistical software package SPSS (ANOVA) for Windows (version 20.0; SPSS Inc., Chicago, Ill.). Student t test was used for comparing between the 2 groups. Results were expressed as mean \pm standard error of mean (S.E.M.). A P value of less than 0.05 was considered significance.

\section{RESULTS}

\subsection{HEMATOLOGICAL FINDINGS:}

\subsubsection{Hematological parameters:}

After $7^{\text {th }}$ day pc significant decrease in hemoglobin concentration and PCV \% was recorded in group 2 when compared with control group. While both parameters showed significant increase in group 4 when compared with group 2. No changes were recorded in the other parameters in the same week and in the $2^{\text {nd }}$ and $3^{\text {rd }}$ week pc. For the platelets count treatment with garlic extract induced significant increase in the plateletes number in group 3 when compared with group1 and group 2, while it recorded signifcant decrease in group 4 in comprsion with group 3. In the $14^{\text {th }}$ day pc significant increase was noticed in group $2 \& 4$ in comparison to group 1 while garlic extract treatment (group 3) induced significant decrease in the thrombocytes when compared with group 2. At the 21th day pc platelets number shown significance increase in group 2 and group 4 when compared with group 1 as shown in Table (1).

\subsubsection{Differential leucocytic counts:}

Table (2) showed non-significant changes in the lymphocytes, neutrophils, monocytes and eosinophil \% in all groups and all times of sacrifications.

\subsection{BIOCHEMICAL ANALYSIS:}

\subsubsection{Liver function tests:}

At $7^{\text {th }}$ day pe Serum liver enzymes activity (AST, ALT and ALP) revealed to significant increase in groups 2 and 4 when compared with group 1 while a significant decrease was recorded in AST and ALT in group 3 when compared with group 2. Moreover, at the $14^{\text {th }}$ day pc, liver enzymes (AST, ALT and ALP) showed significant increase in all exposed groups when compared with group 1. In contrast, a significant decrease in AST and ALP was noticed in groups 3 and 4 when compared with group 2. After 3 weeks PC, the liver serum enzymes revealed significant increase in group 2 when compared with group 1 which decreased significantly after treatment with pure and nanoparticles garlic extracts in comparison to group 2. Total bilirubin showed non-significant changes in all exposed groups $7^{\text {th }}$ day $\mathrm{pc}$, while only total bilirubin increased in group 2 at $14^{\text {th }}$ day pc. In the $21^{\text {th }}$ day pc total bilirubin significantly increased in group2 which decreased significantly after pure and nanoparticles garlic extract treatment as shown in table 3.

Non-significant changes were recorded in total protein and albumin levels in all groups and all times of sacrifications as exhibited in table 3.

\subsubsection{Lipid peroxidation and antioxidant:}

Table (3) showed significant decrease in MDA activity at $7^{\text {th }}$ day pc in groups 3 and 4 when compared with group1 and group2. Moreover, at $14^{\text {th }}$ and 21th day pc, MDA results exhibited recorded significant increase in group 2 which 
decreased significantly in groups 3 and 4 after treatment with pure and nanoparticles extract of garlic when compared with group 1. SOD level decreased at groups 3 at $7^{\text {th }}$ day pc, when compared with control and infected groups while its level decreased significantly in group 4 in comparison to group 1, 2 and 3. At the $14^{\text {th }}$ day pc, significant decrease was detected in group 3 when compared with control and infected groups. The level of SOD exhibited significant decrease in groups 4 when compared with all other groups.

\subsubsection{Oocyst count:}

Table (6) displayed significant decrease in fecal oocyst count in both garlic and nano groups (group 2 \& 3) when compared with infected group (group 1). 
Table (1): The hematological parameters of rabbits of all exposed groups (1, 2, 3 and 4), means $\pm \mathrm{Se} n=5 \mathrm{P}<0.05$.

Parameters

Blood parameters

$\begin{array}{ccccccccc} & \text { RBC's } & \text { Hb. } & \text { PCV } & \text { MCV } & \text { MCH } & \text { MCHC } & \text { WBCs } & \text { Platelets } \\ \text { Groups } & \left(\times 10^{6} / \mathrm{mm}^{3}\right) & (\mathrm{gm} / \mathrm{dl}) & (\%) & (\mathrm{fl}) & (\mathrm{pg}) & \% & \left(\mathrm{x} 10^{3} / \mathrm{mm}^{3}\right) & \left(\mathrm{x} 10^{9} / \mathrm{mm}^{3}\right)\end{array}$

1 week

$\begin{array}{lcccccccc}\text { Group (1) } & 3.7 \pm 0.17 & 11.4 \pm 0.53 & 33.8 \pm 1.4 & 87.8 \pm 1.9 & 30.1 \pm 0.14 & 33.5 \pm 0.08 & 5.8 \pm 0.23 & 213.0 \pm 7.5 \\ \text { Group (2) } & 3.0 \pm 0.19 & 9.3 \pm 0.38^{\mathrm{a}} & 26.8 \pm 1.6^{\mathrm{a}} & 89.0 \pm 0.31 & 30.2 \pm 0.07 & 33.4 \pm 0.06 & 5.0 \pm 0.27 & 200.6 \pm 21.7 \\ \text { Group (3) } & 3.36 \pm 0.05 & 10.2 \pm 0.14 & 29.8 \pm 0.58 & 89.4 \pm 0.60 & 30.3 \pm 0.10 & 33.6 \pm 0.18 & 6.6 \pm 0.53 & 261.6 \pm 17.8^{\mathrm{ab}} \\ \text { Group (4) } & 3.56 \pm 0.06 & 10.8 \pm 0.21^{\mathrm{b}} & 31.8 \pm 0.73^{\mathrm{b}} & 89.6 \pm 0.67 & 30.3 \pm 0.13 & 33.5 \pm 0.09 & 5.9 \pm 0.80 & 188.0 \pm 9.5^{\mathrm{c}} \\ & & & & 2 \text { weeks } & & & \\ \text { Group (1) } & 3.1 \pm 0.09 & 9.5 \pm 0.28 & 28.6 \pm 0.74 & 89.4 \pm 0.4 & 30.3 \pm 0.10 & 33.6 \pm 0.15 & 5.5 \pm 0.19 \\ \text { Group (2) } & 3.2 \pm 0.08 & 9.6 \pm 0.23 & 29.0 \pm 0.89 & 89.6 \pm 0.5 & 30.3 \pm 0.10 & 33.5 \pm 0.13 & 6.3 \pm 0.37 & 209.2 \pm 19.8^{\mathrm{a}} \\ \text { Group (3) } & 3.4 \pm 0.07 & 10.3 \pm 0.22 & 30.6 \pm 0.67 & 89.8 \pm 0.48 & 30.7 \pm 0.07 & 33.6 \pm 0.18 & 6.8 \pm 0.96 & 150.6 \pm 7.5^{\mathrm{b}} \\ \text { Group (4) } & 3.2 \pm 0.11 & 9.6 \pm 0.35 & 28.6 \pm 0.97 & 89.0 \pm 0.44 & 30.4 \pm 0.12 & 33.6 \pm 0.13 & 5.8 \pm 0.48 & 213.8 \pm 22.4^{\mathrm{ac}} \\ & & & & 3 \text { weeks } & & & \\ \text { Group (1) } & 3.1 \pm 0.1 & 9.3 \pm 0.35 & 28.4 \pm 0.67 & 89.2 \pm 0.37 & 30.4 \pm 0.11 & 33.4 \pm 0.13 & 5.1 \pm 0.23 & 175.6 \pm 6.1 \\ \text { Group (2) } & 3.1 \pm 0.06 & 9.3 \pm 0.20 & 27.2 \pm 0.80 & 89.2 \pm 0.37 & 30.4 \pm 0.06 & 33.3 \pm 0.03 & 6.4 \pm 0.39 & 195.6 \pm 8.5^{\mathrm{a}} \\ \text { Group (3) } & 3.14 \pm 0.05 & 9.5 \pm 0.18 & 27.0 \pm 1.7 & 89.6 \pm 0.24 & 30.3 \pm 0.09 & 33.3 \pm 0.04 & 6.5 \pm 0.71 & 189.0 \pm 10.9 \\ \text { Group (4) } & 3.16 \pm 0.04 & 9.6 \pm 0.13 & 28.4 \pm 0.50 & 89.8 \pm 0.20 & 30.5 \pm 0.07 & 33.3 \pm 0.02 & 6.3 \pm 0.71 & 196.6 \pm 11.0^{\mathrm{a}}\end{array}$

$\mathrm{a} \rightarrow$ significant difference when compared with group 1 when $\mathrm{P}<0.05 \quad \mathrm{~b} \rightarrow$ significant difference when compared with group 2 when $\mathrm{P}<0.05$

$\mathrm{c} \rightarrow$ significant difference when compared with group 3 when $\mathrm{P}<0.05$. 
Table (2): Leukocytic counts and Differential leukocytic counts of lymphocytes, neutrophil, monocytes, and eosinophil \% of rabbits of all exposed groups $(1,2,3$ and 4$)$, means $\pm S E, n=5, P<0.05$.

Parameters leukocytic counts

$\begin{array}{lcc}\text { Groups } & \begin{array}{c}\text { WBCs } \\ \left(\times 10^{3} / \mathrm{mm}^{3}\right)\end{array} & \text { Lymphocytes } \\ \text { Group (1) } & 5.8 \pm 0.23 & 56.8 \pm 1.8 \\ \text { Group (2) } & 5.0 \pm 0.27 & 55.4 \pm 1.2 \\ \text { Group (3) } & 6.6 \pm 0.53 & 57.6 \pm 1.6 \\ \text { Group (4) } & 5.9 \pm 0.80 & 56.0 \pm 2.0 \\ & & \\ \text { Group (1) } & 5.5 \pm 0.19 & 59.8 \pm 3.0 \\ \text { Group (2) } & 6.3 \pm 0.37 & 56.2 \pm 3.0 \\ \text { Group (3) } & 6.8 \pm 0.96 & 61.2 \pm 2.6 \\ \text { Group (4) } & 5.8 \pm 0.48 & 58.6 \pm 2.6 \\ & & \\ \text { Group (1) } & 5.1 \pm 0.23 & 55.8 \pm 2.5 \\ \text { Group (2) } & 6.4 \pm 0.39 & 53.8 \pm 0.9 \\ \text { Group (3) } & 6.5 \pm 0.71 & 59.6 \pm 1.6 \\ \text { Group (4) } & 6.3 \pm 0.71 & 55.4 \pm 2.1\end{array}$

Differential leukocytic counts

$\begin{array}{rcc}\text { Neutrophil } & \text { Monocytes } & \text { Eosinophil } \\ 1 \text { week } & & \\ 40.2 \pm 1.2 & 2.0 \pm 0.3 & 1.0 \pm 0.3 \\ 41.6 \pm 1.3 & 2.2 \pm 0.37 & 1.2 \pm 0.37 \\ 39.0 \pm 1.4 & 2.2 \pm 0.2 & 1.2 \pm 0.2 \\ 40.0 \pm 1.8 & 2.4 \pm 0.24 & 1.6 \pm 0.24 \\ 2 \text { weeks } & & \\ 37.2 \pm 2.8 & 2.0 \pm 0.31 & 1.0 \pm 0.3 \\ 40.6 \pm 3.0 & 2.0 \pm 0.31 & 1.6 \pm 0.24 \\ 36.0 \pm 2.6 & 1.8 \pm 0.37 & 1.0 \pm 0.31 \\ 38.2 \pm 2.2 & 2.2 \pm 0.37 & 1.0 \pm 0.31 \\ 3 \text { weeks } & & \\ 40.4 \pm 2.6 & 2.4 \pm 0.24 & 1.4 \pm 0.24 \\ 43.0 \pm 1.2 & 2.2 \pm 0.21 & 1.4 \pm 0.24 \\ 37.0 \pm 1.7 & 2.2 \pm 0.2 & 1.2 \pm 0.2 \\ 40.8 \pm 1.9 & 2.6 \pm 0.24 & 1.2 \pm 0.37\end{array}$


Table (3): liver function tests and The concentration of MDA and SOD oxidative markers in serum of all exposed groups (1,2, 3 and 4), means \pm SE, $n=5, P<0.05$.

Parameters

\begin{tabular}{|c|c|c|c|c|c|c|c|c|}
\hline Groups & AST(IU/l) & ALT (IU/l) & ALP (IU/l) & $\begin{array}{c}\text { Total } \\
\text { bilirubin } \\
(\mathrm{mg} / \mathrm{dl}) \\
\text { week }\end{array}$ & $\begin{array}{c}\text { Total } \\
\text { protein } \\
(\mathrm{g} / \mathrm{dl})\end{array}$ & $\begin{array}{l}\text { Albumin } \\
\text { (g/dl) }\end{array}$ & $\begin{array}{l}\text { MDA } \\
(\mathrm{mmol} / \mathrm{l})\end{array}$ & SOD(IU/1) \\
\hline Group (1) & $69.2 \pm 6.1$ & $63.1 \pm 6.9$ & $127.4 \pm 21.1$ & $0.24 \pm 0.02$ & $5.2 \pm 0.10$ & $3.6 \pm 0.06$ & $12.2 \pm 2.2$ & $318.1 \pm 6.8$ \\
\hline Group (2) & $87.4 \pm 18.3^{a}$ & $73.5 \pm 6.7^{\mathrm{a}}$ & $\begin{array}{c}113.9 \pm 10.2 \\
\mathrm{a}\end{array}$ & $0.32 \pm 0.03$ & $4.3 \pm 0.17$ & $3.4 \pm 0.06$ & $12.4 \pm 1.0$ & $317.2 \pm 8.7$ \\
\hline Group (3) & $67.7 \pm 7.6^{b}$ & $60.4 \pm 6.6^{b}$ & $121.2 \pm 18.7$ & $0.20 \pm 0.03$ & $5.0 \pm 0.2$ & $3.4 \pm 0.05$ & $5.2 \pm 0.79^{\mathrm{ab}}$ & $\begin{array}{c}294.8 \pm 9.1 \\
\text { ab }\end{array}$ \\
\hline Group (4) & $86.0 \pm 4.4^{\mathrm{ac}}$ & $64.9 \pm 5.6^{\mathrm{b}}$ & $\begin{array}{c}103.6 \pm 20.1 \\
a\end{array}$ & $0.14 \pm 0.02$ & $5.1 \pm 0.1$ & $3.6 \pm 0.1$ & $5.7 \pm 0.94^{\mathrm{ab}}$ & $\begin{array}{c}260.5 \pm 38 . \\
6^{\mathrm{abc}}\end{array}$ \\
\hline \multicolumn{9}{|c|}{2 weeks } \\
\hline Group (1) & $65.1 \pm 2.4$ & $57.9 \pm 2.6$ & $115.7 \pm 14.2$ & $0.28 \pm .03$ & $5.5 \pm 0.08$ & $3.8 \pm 0.07$ & $11.0 \pm 1.2$ & $301.0 \pm 8.9$ \\
\hline Group (2) & $109.6 \pm 7.7^{\mathrm{a}}$ & $69.5 \pm 6.0^{\mathrm{a}}$ & $\begin{array}{c}181.0 \pm 11.7 \\
\mathrm{a}\end{array}$ & $0.52 \pm .05^{\mathrm{a}}$ & $5.3 \pm 0.13$ & $3.2 \pm 0.25$ & $18.4 \pm 2.0^{\mathrm{a}}$ & $\begin{array}{c}289.6 \pm 16 \\
5\end{array}$ \\
\hline Group (3) & $77.6 \pm 4.4^{\mathrm{ab}}$ & $63.6 \pm 5.5$ & $\begin{array}{c}132.9 \pm 11.3 \\
\mathrm{ab}\end{array}$ & $0.38 \pm 0.05$ & $5.8 \pm 0.08$ & $3.8 \pm 0.04$ & $6.5 \pm 1.6^{\mathrm{ab}}$ & $\begin{array}{c}272.4 \pm 16 . \\
8^{a b}\end{array}$ \\
\hline Group (4) & $85.3 \pm 3.3^{\mathrm{ab}}$ & $64.4 \pm 3.3^{\mathrm{a}}$ & $\begin{array}{c}124.4 \pm 9.0 \\
\mathrm{ab}\end{array}$ & $0.42 \pm 0.06$ & $5.4 \pm 0.15$ & $3.5 \pm 0.13$ & $7.2 \pm 1.6^{\mathrm{ab}}$ & $\begin{array}{c}259.5 \pm 37 \\
5\end{array}$ \\
\hline \multicolumn{9}{|c|}{3 weeks } \\
\hline Group (1) & $75.1 \pm 4.9$ & $61.2 \pm 6.0$ & $124.4 \pm 8.3$ & $0.24 \pm 0.05$ & $5.7 \pm 0.39$ & $3.6 \pm 0.05$ & $9.6 \pm 1.2$ & $\begin{array}{c}293.0 \pm 44 . \\
5\end{array}$ \\
\hline Group (2) & $111.1 \pm 8.3^{\mathrm{a}}$ & $80.3 \pm 4.3^{\mathrm{a}}$ & $189 \pm 23.4^{\mathrm{a}}$ & $0.56 \pm 0.05^{\mathrm{a}}$ & $4.9 \pm 0.1$ & $3.1 \pm 0.27$ & $17.3 \pm 3.0^{\mathrm{a}}$ & $\begin{array}{c}289.5 \pm 31 \\
6\end{array}$ \\
\hline Group (3) & $69.4 \pm 11.4^{b}$ & $56.7 \pm 2.9^{b}$ & $127.1 \pm 7.9^{b}$ & $0.20 \pm 0.03^{b}$ & $5.28 \pm 0.11$ & $3.7 \pm 0.08$ & $3.7 \pm 0.58^{\mathrm{ab}}$ & $\begin{array}{c}293.1 \pm 17 \\
0\end{array}$ \\
\hline Group (4) & $73.9 \pm 5.3^{b}$ & $59.9 \pm 8.8^{\mathrm{b}}$ & $\begin{array}{c}144.9 \pm 20.0 \\
\text { abc }\end{array}$ & $0.18 \pm 0.03^{b}$ & $5.0 \pm 0.08$ & $\begin{array}{c}3.66 \pm 0.0 \\
6\end{array}$ & $2.9 \pm 0.50^{\mathrm{ab}}$ & $\begin{array}{c}267.2 \pm 33 . \\
0^{\mathrm{abc}}\end{array}$ \\
\hline
\end{tabular}

\section{Liver function tests and antioxidant}

$a \rightarrow$ significant difference when compared with group 1 when $P<0.05$

$b \rightarrow$ significant difference when compared with group 2 when $P<0.05$

$c \rightarrow$ significant difference when compared with group 3 when $P<0.05$. 
Table (4): Number of fecal oocystes per gram feces of rabbits of groups (2, 3 and 4), means \pm Se $\mathrm{n}=5 \mathrm{P}<0.05$.

\section{Parameter}

Groups

Group (2)

Group (3)

Group (4)

\section{Fecal oocyst count /gm $\times 10^{3}$}

$670.0 \pm 61.5$

$302.2 \pm 18.0^{\mathrm{a}}$

$320.0 \pm 48.2^{\mathrm{a}}$

$\mathrm{a} \rightarrow$ significant difference when compared with group 1 (infected) when $\mathrm{P}<0.05$

\section{DISCUSSION}

Eimeria stiedae is one of the most pathogenic species of domestic rabbits. E. stiedae parasitizes the epithelial cells of the bile duct causing severe liver damage and great economic losses (Eckert et al ., 1995; Zerrin and Yesari, 2006). In this study we used one of the medicinal plants (garlic extract and garlic nanoparticles) to investigate their antiparasitic effects against Eimeria stiedae.

Hematological findings showed After $7^{\text {th }}$ day pc significant decrease in hemoglobin concentration and PCV \% in group 2 when compared with control group. While both parameters showed significant increase in group 4 when compared with group2. The increase in hemoglobin concentration, packed cell volume and red blood cells count at groups 4 compared with infected group may be possible related to the end product of garlic metabolism in the body that stimulates the kidney directly to cause formation and secretion of erythropoietin (a potent stimulator of the bone marrow) (Iranloye, 2002).

Serum liver function testes referred to significant increase in the enzymatic activities of AST, ALT, Alkaline phosphatase (San
Martin- Nun $\asymp$ et al ., 1988) and total bilirubin in group 2 in comparison with control group. While, these enzymes showed significant decrease in group $3 \& 4$ in comparison with group 2. These results due to garlic decrease hepatic injury caused by Eimeria stiedae infection Garlic significantly diminishes liver injury and inflammation and therefore can be considered as a hepatoprotective agent.(Gedik et al., (2005) have reported that one of the major protective functions of garlic is to decrease the oxidative damage in liver.

Serum antioxidant showed a significant increase in MDA level was noticed in groups 2 when compared with control. This could be attributed to enhanced immune cell activity causing the overproduction of free radicals (Allen, 1996). Higher MDA levels in infected rabbits are probably due to oxidative stress occurring after the coccidial infection. Similar results on oxidative stress in parasitic diseases have been reported by others (Allen, 1996; Allen, 1997; Guarrera, 1999 !Georgieva et al., 2006; Wang et al., 2008). On the other hand, groups $3 \& 4$ revealed significant reduction in MDA values when compared with group 2, garlic decreased concentrations of MDA, compared to infected group. This result is 
similar to the findings of Dkhil et al. (2011) who showed that garlic treatment lowered MDA.

The result of this study showed reduction in oocyst per gram of feces in animals treated with garlic extract and garlic nanoparticles and this is in agreement with Abu- Akkada et al., (2010) who showed there is a reduction in oocyst per gram of feces of animals treated and protective with garlic. Other study (Worku et al., 2009) whom studied the effectiveness of garlic for controlling gastrointestinal parasites in adult female goats which naturally infected with haemonchus contortus and coccidia by measuring fecal egg count, Significant decrease in the numbers of coccidia oocyst was observed in goats which received high dose $(10 \mathrm{ml})$ of garlic extract and reduction in eggs per gram of feces for $h$. contortus. In our study the result indicated that the reduction in oocyst per gram of feces in animals treated with garlic extract more than that of garlic nanoparticle group.

In conclusion: Both garlic nanoparticles and pure garlic extracts have anti-parasitic effects against Eimeria Steidai with little difference in between the both groups.

\section{REFERENCES}

Abu-Akkada S.; Oda.S.S.; Ashmawy.K.I.,(2010).Garlic and hepatic coccidiosis prophylaxis or treatment? Trop anim health prod.42:1337 -1343.

Allen, PC(1996). Production of free radical species during Eimeria maxima infections in chickens. Poult. Sci., 76 : 814-821.
Allen, PC(1997). Nitric oxide production during Eimeria tenella infections in chickens. Poult. Sci., 76: 810-813.

Amagase, H., Petesch, B.L., Matsuura, H., Kasuga, S. and Itakura, Y. Intake of garlic and its bioactive components. J Nutr, 131:955-962,2001.

Ankri, S., Miron, T., Rabinkov, A., Wilchek, M. and Mirelman, D. Allicin from garlic strongly inhibits cysteine proteinases and cytopathic effects of Entamoeba histolytica. Antimicrobial Agents and Chemotherapy 10, 22862288, 1997.

Ankri, S. and Mirelman, D. Antimicrobial properties of allicin from garlic. Microbes Infect, 1:125-129, 1999.

Anthony, J.P., Fyfe L. and Smith, H. Plant active components - a resource for antiparasitic agents? Trends Parasitol 21:462-468, 2005.

Antony, M.L. and Singh, S.V. Molecular mechanisms and targets of cancer chemoprevention by garlic-derived bioactive compound diallyl trisulfide. Indian J Exp Biol, 49:805-816, 2011

Coppi, A., Cabinian, M., Mirelman, D. and Sinnis, P. Antimalarial activity of allicin, a biologically active compound from garlic cloves. Antimicrob Agents Chemother, 50:1731-1737, 2006.

Dkhil, MA; Abdel-Bakia, AS; Wunderlicha, F; Siesa, $H$ and Al-Quraishya, S(2011).Anticoccidial and antiinflammatory activity of garlic in murine Eimeria papillata infections. Vet. Parasitol., 175: 66-72.

Eckert, J., R. Braun, M.W (1995): Shirley and T. Coudert, Separation 1995. 
Biotechnology: Guidelines on techniques in coccidiosis research. EEc-EAEC, Brussels, Luxembourg.

Gamboa-Leon, M.R., Aranda-Gonzalez, I., Mut-Martin, M., Garcia-Miss M.R. and Dumonteil, E. In vivo and in vitro control of Leishmania mexicana due to garlic-induced NO production. Scand J Immunol, 66:508-514, 2007.

Gedik,N., Kabasakal, L., Sehirli, O., Ercan, F., Sirvanci, S., Keyer-Uysal, M‘.Sener, G., 2005. Long-term administration of aqueous garlic extract(AGE) alleviates liver fibrosis andoxidative damage induced by biliary obstruction in rats. Life Sci. 76, 2593-2606

Georgieva, NV; Koinarski, V and Gadjeva, $\mathrm{V}(2006)$. Anti-oxidant status during the course of Eimeria tenella infection in broiler chickens. Vet. J., 172: 488-492

Guarrera, $\quad$ PM(1999). $\quad$ Traditional antihelmintic, antiparasitic rand repellent uses of plants in Central Italy. J .Ethnopharmacol., 68: 183-192.

Hung, L.X., Chen, F.Q. and Lin, Y.G., Studies on the coccidian of rabbit, with a note on the endogenous stages and histopathology of Eimeria stiedae. Wuyi Science Journal, 4, 55-64, 1984.

Iranloye, B.O., "Effect of chronic garlic feeding on some haematologicaparameters", Afr. J. Biomed. Res., 5: 81-82, 2002.

Khanum, Anilakumar,

K.R., Sudarshanakrishna, K.R. and Viswanathan, K.R. Effects of feeding fresh garlic and garlic oil on 1 detoxifying enzymes and micronuclei formation in rats treated with azoxymethane, International Journal Vitam Nutr Res;68(3):208-13, 1998.
Leela; M. and Vivekanandan. A.Tapping the unexploited plant resources for the synthesis of silver nanoparticles African.J.of Biotechnol, 7, 3162-3105, 2008.

Long, P.L. and Joyner, L.P. A guide to a laboratory techniques used in the study and diagnosis of avian coccidiosis. Folia Veterinaria Latina, 6,201-207, 1976.

Lun, Z.R., Burri, C., Menzinger, M. and Kaminsky, R. Antiparasitic activity of diallyl trisulfide (Dasuansu) on human and animal pathogenic protozoa (Trypanosoma sp., Entamoeba histolytica and Giardia lamblia) in vitro. Ann Soc Belg Med Trop, 74:5159, 1994.

Luo, D. Q., Guo, J. H., Wang, F. J., Jin, Z. X., Cheng, X. L., Zhu, J. C., Peng, C. Q. and Zhang, C. 2009. Anti-fungal Efficacy of Polybutylcyanoacrylate Nanoparticles of Allicin and Comparison With Pure Allicin. Journal of Biomaterials Science 20, 21-31.

Mantawy, M.M., Ali, H.F. and Rizk, M.Z. Therapeutic effects of Allium sativum and Allium cepa in Schistosoma mansoni experimental infection. Rev Inst MedTrop São Paulo, 53:155-163, 2011.

McCarron, P. A., Donnelly, R. F. and Marouf, W. Anti-adherent and antifungal activities of surfactant-coated poly(ethylcyanoacrylate) nanoparticles Int. J. Pharm. 340, 182, 2007.

McMahon, F.G. and Vargas, R. Can garlic lower blood pressure? A pilot study. Pharmacotherapy; 13:406ะ7, 1993. 
Moghimi, S. M. Hunter A. C. and Murray, J. C. Long-circulating and target-specific nanoparticles: theory to practice Pharmacol. Rev. 53, 283, 2001.

Nagini, S. Cancer chemoprevention by garlic and its organosulfur compoundspanacea or promise? Anticancer Agents Med Chem, 8:313-321, 2008.

Nahed, H.A., Hoda, A.T. and Yomna, I.M. Effects of garlic on albino mice experimentally infected with Schistosoma mansoni: a parasitological and ultrastructural study. Trop Biomed, 26:40-50, 2009.

Perez. H.A., De la Rosa, M. and Apitz, R. In vivo activity of ajoene against rodent malaria. Antimicrob Agents Chemother, 38:337-339, 1994.

Phelps, S. and Harris, W.S. Garlic supplementation and lipoprotein oxidation susceptibility. Lipids;

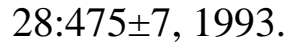

Ramoutar, R.R. and Brumaghim, J.L. Antioxidant and anticancer properties and mechanisms of inorganic selenium, oxo-sulfur, and oxo-selenium compounds. Cell Biochem Biophys, 58:1-23, 2010.

Rivlin, R.S. Historical perspective on the use of garlic. J Nutr 131, 951S-954S, 2001.

SanMartin-Nun` ez, B.V., Ordon` ezEscudero, D., Alunda, J.M., 1988.Preven-tive treatment of rabbit coccidiosis with adifluoromethylornithine. Vet. Parasitol. $30,1-10$
Sun, X. and $\mathrm{Ku}, \mathrm{D} . \mathrm{D}$. Allicin in garlic protects against coronary endothelial dysfunction and right heart hypertrophy in pulmonary hypertensive rats. Am J Physiol Heart Circ Physio 291:H2431-H2438, 2006.

Tsao, S.M \& Yin, M.C. In-vitro antimicrobial activity of four diallyl sulphides occurring naturally in garlic and Chinese leek oils. J Med Microbiol 50, 646-649, 2001.

Wabwoba, B. W., Anjili, C. O., Ngeiywa, M. M., Ngure, P. K., Kigondu, E. M., Ingonga, J., and Makwali, J. Experimental chemotherapy with Allium sativum (Liliaceae) methanolic extract in rodents infected with Leishmania major and Leishmania donovani. J Vector Borne Dis 47, 160167, 2010.

Wang, ML; Suo, X; Gu, JH; Zhang, WW; Fang, Q and Wang, X(2008). Influence of grape seed proanthocyanidin extract in broiler chickens: effect on chicken coccidiosis and antioxidant status. Poult. Sci., 87: 2273-2280 .

Worku,M., Franco ,R., and Baldwin, K.(2009). Efficacy of of garlic as an antihelmint ic in adult boer goats. Arch of biological science ‘ Belgrade,61(1),135-140.

Zerrin, E.S. and E. Yesari, (2006): DS Hepatic Coccidiosis in Angora Rabbits. J. Ani., Vet. Adv., 5: 462-463. 